UNRAM Law Review is licensed under a Creative Commons Attribution 4.0 International License, which permits unrestricted use, distribution, and reproduction in any medium, provided the original work is properly cited. p-ISSN: 2548-9267 | e-ISSN : 2549-2365, Open Access at : http://unramlawreview.unram.ac.id/index.php/ulr

\begin{tabular}{c|c|c|c|c|}
\hline Volume & Issue & Page & April & p-ISSN: 2548-9267 \\
\hline 4 & 1 & $64-73$ & 2020 & e-ISSN : 2549-2365
\end{tabular}

\title{
Diversion in the Child Criminal Justice System as an Effort to Implement Restorative Justice
}

\author{
Dewi Setyowati \\ Faculty of Law \\ University of Hang Tuah \\ E-mail: dewi.setyowati@hangtuah.ac.id
}

\begin{abstract}
The juvenile criminal justice system according to Article 1 of Law Number 11 Year 2012 concerning the Criminal Justice System for Children (hereinafter referred to as SPPA Law) is the whole process of resolving cases of children in conflict with the Law from the investigation stage to the guidance stage after undergoing a crime. The application of SPPA involves many parties consisting of the police, prosecutors, legal advisors, courts, and correctional institutions, and child development. One of the law enforcers (structures) in SPPA that has a significant role is the prosecutor's office. The Prosecutor's Office as the prosecuting body that has been given the authority to solve the problems of children in conflict with the Law (hereinafter referred to as $A B H$ ) by using diversion to realize Restorative Justice, as stipulated in the provisions of Article 7 Paragraph 1 of the SPPA Law. What if, in this stage, the diversion was not sought for ABH? What is the form of violations experienced by ABH in the criminal justice system, especially at the prosecution stage? The method used is legal/normative research based on laws and regulations relating to one another. The Indonesian Attorney's Office in the constitutional system, as a body related to judicial authority, with a very dominant function as the dominus litis principle, controls the case process that determines whether a person can be declared a defendant and is submitted to the Court based on legal evidence according to the Law, and as ambtenaar executive implementing the decision and court decisions in criminal cases. The SPPA Law material test is a struggle in the context of maintaining the constitutional rights of law enforcers in their duty and is not intended to reject diversion in handling $A B H$. This provision is related to the protection of the law enforcement profession guaranteed by the constitution. Even though the Supreme Court has declared article 96 of the SPPA Law being applied unconstitutional or revoked, it does not mean allowing law enforcers the police, judges, and prosecutors not to carry out diversion obligations.
\end{abstract}

Keywords: restorative justice; children; diversion.

\section{INTRODUCTION}

Cases of Children in conflict with the law (hereinafter referred as to ABH children) in Indonesia are increasing every year ${ }^{1}$, based on the report of the Indonesian Child Protection Commission (hereinafter referred to as KPAI), from 2011 to 2019 the number of ABH cases reported to KPAI reached 11,492 cases. In terms of handling ABH, Indonesia has used the Juvenile Justice System concept which adopted the United Nations Standard

1 SetyaWahyudi. (2011). Implementasi Ide Diversi Dalam Pembaharuan Sistem Peradilan Pidana Anak di Indonesia. Yogyakarta: Genta Publishing, p. 1. 
Minimum Rules for the Administration of Juvenile Justice or The Beijing Rules ${ }^{2}$, which was then implemented into Law Number 11 of 2012 concerning the Juvenile Justice System.

The birth of the SPPA Act itself aims to promote welfare and ensure that children will receive special treatment for violations of the law involving children. The understanding of the juvenile justice system according to Article 1 of the SPPA Law, is; the whole process of resolving cases of children dealing with the law from the investigation stage to the guidance stage after undergoing a crime. So that the application of SPPA involves many parties consisting of the police, prosecutors, legal advisors, courts, and correctional institutions and child development ${ }^{3}$.

One of the law enforcers in SPPA who has a major role is the prosecutor's office. The prosecutor's office as a prosecuting agency that is given the authority to resolve ABH issues by using diversion to realize Restorative Justice, as stipulated in the provisions of Article 7 Paragraph 1 of the SPPA Law which reads:

At the level of investigation, prosecution and examination of cases of children in the state court must be pursued by Diversion.

What is interesting in this SPPA Act is there are cumulative sanctions in the form of administrative sanctions and criminal threats against law enforcers, for example public prosecutors who deliberately do not carry out their obligations to seek diversion in $\mathrm{ABH}$ cases, as regulated in articles 95 and 96 of the SPPA Law which reads:

\section{Article 95}

Officials or officers who violate the provisions referred to in article 7 paragraph (1), article 14 paragraph (2), article 17, article 18, article 21 paragraph (3), article 27 paragraph (1) and paragraph (3), article 29 paragraph (1), article 39, article 42 paragraph (1) and paragraph (4), article 55 paragraph (1), and article 62 are subject to administrative sanctions in accordance with statutory regulations.

\section{Article 96}

Investigators, public prosecutors and judges who deliberately did not carry out the obligations referred to in article 7 paragraph (1) shall be sentenced to a maximum imprisonment of 2 (two) years or a maximum fine of Rp 200,000,000 (two hundred million rupiah) ${ }^{4}$

The threat of criminal action against law enforcers ${ }^{5}$, if intentionally not carrying out an obligation to seek diversion, is a form of the country's seriousness to protect the rights of children as perpetrators, victims and witnesses. Because in practice investigators and public prosecutors sometimes continue to proceed to the level of prosecution ${ }^{6}$ without attempting diversification in advance of cases involving $\mathrm{ABH}$, as in the case of theft that occurred in Purbalingga district in 2014 where three duck thieves were sentenced to 2.5 years without diversion attempts. First by law enforcement ${ }^{7}$.

It can be imagined the magnitude of loss experienced by an $\mathrm{ABH}$ who does not get diversionary efforts by the public prosecutor. Considering that diversionary effort for law enforcement is an obligation as regulated in article 7 paragraph (1) of the SPPA Law, so that legal efforts by ABH parents need to be done, children obtain the right to be sought diversion as a form of restorative

2 United Nations Standard Minimum Rules For The Administration Of Juvenile Justice. Here in after referred as The Beijing Rules.

3 Ibid, p. 35.

4 Which article 96 of the SPPA Law has been declared does not have the strength of the law to bind since the verdict of the Constitutional Court Number 110 / PUU-X / 2012.

5 Which in the law enforcers, in particular is the public prosecutor.

6 Diversi, www.icjr.or.id, accessed at $10^{\text {th }}$ October 2019 ..

7 Assrorun Niam. KPAI Sayangkan Vonis PN Purbalingga Yang Penjarakan 3 Anak Pencuri Bebek, https: news.detik.com, Kamis 28 Agustus 2014, accessed at 10 ${ }^{\text {th }}$ October 2019. 
justice. However, in practice, parents of $\mathrm{ABH}$ rarely take legal action. ${ }^{8}$ This practice happens because $\mathrm{ABH}$ parents find it difficult to prove the element of error committed by the public prosecutor and are confused about legal remedies that can be made, considering the provisions of article 97 of the SPPA Law has been declared not has binding legal force since the decision of the Constitutional Court Number $11 \cdot /$ PUU-X / $r \cdot 1 r$.

What if, in this stage, the diversion was not sought for $\mathrm{ABH}$, the form of violations experienced by $\mathrm{ABH}$ in the criminal justice system, especially at the prosecution stage?

\section{METHOD}

This research uses the normative legal research method. Normative research is research conducted by examining library materials. The data used in this study are secondary data that includes primary legal material that is legislation. This study also uses secondary legal material that is legal material that provides an explanation of primary legal material, such as research results, work from legal circles. This study also uses tertiary legal materials, such as language dictionaries and legal dictionaries. ${ }^{9}$ In this research, the primary tool for data collection is in the form of document studies or literature studies. In this research, data collection conducted by the method of literature study, which conducted by collecting, reviewing, and processing literature, legislation and articles, journals, and scientific works as a supporter of theory in writing and discussion of research. Data obtained from this study, both from primary and secondary legal materials, as well as tertiary legal materials, are described and then analyzed qualitatively, namely by studying, analyzing, and interpreting any data that has collected. The results of the analysis are described in sentence form systematically to make it easy to conclude the data.

\section{ANALYSIS AND DISCUSSION}

\section{Restorative Justice and Diversion}

The term justice (Justitia) comes from the word fair, which means to be impartial, to the right, and not arbitrary. ${ }^{10}$ According to John Rawls, justice is a principle of rational policy which applied to the conception of the amount of the welfare of community groups. ${ }^{11}$ According to Aristotle, Justice consisting of treating equally and unqualified in proportion to their inequality, which means that for the same things, they are treated equally and those that are not treated equally, proportionally. ${ }^{12}$

Referring to some definitions can be understood that justice is all matters relating to attitudes and actions in human relations that contain a demand to treat someone by their rights and obligations. One of the instruments for realizing legal justice in order to fulfill one's rights and obligations is to apply the concept of restorative justice.

Restorative justice developed by UNICEF based on international legal instruments for children who have legal problems, one of which is The Beijing Rules. This concept emphasizes justice, which can restore conditions for children as perpetrators of crime, children as victims

8 Legal remedy is an appeal to the law by the parents if there are no diversion attemps by the general prosecutor.

9 Soerjono Soekanto dan Sri Mamudji. (2014). Penelitian Hukum Normatif: Suatu Tinjauan Singkat. Ed. 1. Cet. 16. Jakarta: Rajawali Pers, p. 13.

10 John Rawls. (2015). A theory of justice. Cambridge: Belknap press, 1971 p.103 in M.Helmi, Jurnal Konsep Keadilan Dalam Filsafat Hukum.

11 Ibid.

12 O. Notohamidjojo. (1971). Masalah Keadilan. Semarang: TirtaAmerta, p.7.

66 Dewi Setyowati | Diversion in the Child Criminal Justice System as an Effort to... 
of crime and disturbed communities. ${ }^{13}$ Restorative Justice focuses on crime as loss/damage and justice (justice) which is an effort to repair the damage with a vision to elevate the role of victims of crime, perpetrators and the community as three critical determinant dimensions in the criminal justice system for the welfare and security of the community. ${ }^{14}$

The definition of restorative justice, under article 1 paragraph (6) of the SPPA Law is the settlement of criminal cases involving the perpetrators, victims, families of victims/ perpetrators, and related parties to jointly seek a fair resolution by emphasizing restoration back to its original state and not retaliation. Bagir Manan elaborates on the substance of restorative justice, which contains the principles of settlement, which are considered fair for all parties (win-win solutions). ${ }^{15}$ One form of restorative justice efforts in handling child cases, which known in the SPPA Law, is diversion, which in Indonesian terms is called diversion or diversion.

The definition of diversion, according to Jack E. Bynum in his book "Juvenile Delinquency a Sociological Approach", states ${ }^{16}$ :

Diversion is an attempt to divert, or channel out, youthful offender from the juvenile justice system.

In the opinion of Peter C. Kratcoski, there are three types of diversion programs that can be implemented, namely ${ }^{17}$ :

a) The implementation of social control (social control orientation), namely law enforcement officials surrender the perpetrators in the responsibility of supervision or observation of the community, with observance of the approval or warning given. Perpetrators accept responsibility for their actions and do not expect a second chance for perpetrators by the community.

b) Social services by the community to the perpetrators (social service orientation), namely carrying out functions to supervise, interfere, improve, and provide services to the offender and his family. The community can interfere with the offender's family to provide repairs or services.

c) Towards a process of restorative justice or balanced (restorative justice orientation), which protects the community, allows the actor to be directly responsible to the victim and the community and to make a joint agreement between the victim and the victim. $T$ he implementation is, all related parties brought together to reach an agreement on the actions of the perpetrators.

Definition of Diversion, according to Article 1 paragraph (7) of SPPA Law, is the transfer of the settlement of a child case from the criminal justice process to the process outside of criminal justice. Based on the description above, then in the case of settlement of cases that use diversion can only be used in criminal cases involving children or children in conflict with the law.

\section{Prosecution}

Definition of the Prosecutor's Office under Article 1 point 1 of the Law of the Republic of Indonesia Number 16 Year 2004 Concerning the Prosecutor's Office, the Prosecutor's Office is a functional official authorized by this law to act as a public prosecutor and executor of court decisions that have obtained legal force and other authorities based on the law. The

13 Wagiati. Loc.Cit, p.134.

14 Muladi. (2013). Restorative Justice Dalam Sistem Peradilan Pidana Dan Implementasinya Dalam Penyelesaian Tindak Pidana Yang Dilakukan Anak-Anak. BPHPN, p.1.

15 Ibid.

16 Marlina. (February 2008), "Penerapan Konsep Diversi Terhadap Anak Pelaku Tindak Pidana Dalam Sistem Peradilan Pidana Anak", Jurnal Equality, Vol. 13. No.1. p.97.

17 Marlina, Op.Cit, p. 98. 
Prosecutor's Office as a law enforcement and justice institution is demanded to play a more significant role in upholding the rule of law, protecting public interests and upholding human rights $^{18}$, so that the Prosecutor's Office is in the process of being pivoted and filtering the process of investigation and examination process as well as implementing the decision and court decision.

The Prosecutor's Office is the controller of the case process (Dominus Litis), because only the Prosecutor's institution can determine whether a case can be submitted to the Court or not based on legal evidence according to the Criminal Procedure Code ${ }^{19}$. In addition to playing a role in criminal cases, the AGO also has another role in Civil Law and State Administration ${ }^{20}$.

In Article 30 of the Prosecutor's Law, the duties and authorities granted to the Prosecutor's Office broadly cover the area of criminal, civil, administrative Law, and also include public order. The Prosecutors' Office in the criminal field has the following duties and authorities:

a. Prosecute;

b. Carry out the determination of judges and court decisions that have obtained permanent legal force;

c. Supervise the implementation of conditional criminal decisions, supervise criminal decisions, and conditional release decisions;

d. Investigate certain criminal acts based on the Law;

e. Complete specific case files and to do so can carry out additional examinations before being handed over by the court which in its implementation coordinated with the investigator;

Based on the analysis of Article 30 of the Prosecutor's Law above, concluded that the prosecutor's office was given the authority to conduct prosecutions carried out by a public prosecutor. The definition of a public prosecutor in Article 1 paragraph 6 letters (b) of the Criminal Procedure Code is a prosecutor who is authorized by this Law to prosecute and implement the determination of a judge. ${ }^{21}$

Public prosecutor has the authority to prosecute anyone who is charged with a criminal offense in his jurisdiction by referring the case to the court authorized to adjudicate. The authority of the public prosecutor if elaborated is as follows:

a. The authority to receive notification from the investigator in the event that after the commencement of the investigation of a criminal offense as in Article 109 paragraph 1, and also Article 6 paragraph 1 letter $\mathrm{b}$ regarding an investigation is terminated by law.

b. Receive the first and second stage dossiers as referred to in Article 8 paragraph (3) letters $\mathrm{a}$ and $\mathrm{b}$ in the event that a short examination process receives a case file directly from the auxiliary investigator (Article 12)

c. Holding pre-prosecution as referred to in Article 14 letter b

d. Detain (Article 20 paragraph 2) and extend the detention (Article 124 paragraph 20) and transfer the type of detention.

e. Carry out "Other actions" within the scope of duties and responsibilities as Public Prosecutor (Article 14 letter i)

f. Or carry out other tasks given by the legislation.

\section{Children in conflict with the law (ABH)}

18 Abdi Reza. (2012). Tesis: Peran Jaksa Dalam Menerapkan Konsep Diversi Terhadap Anak Yang Berkonflik Dengan Hukum. Jakarta: Fakultas Hukum UI, p.71.

19 Tentang Kejaksaan, www.kejaksaan.go.id, accessed at 20 $0^{\text {th }}$ September 2019.

20 Ibid.

21 M. Karjadi dan R. Soesilo. (1988). Kitab Undang-Undang Hukum Acara Pidana Dengan Penjelasan Resmi Dan Komentar. Bogor: Politeia, p 3.

68 Dewi Setyowati | Diversion in the Child Criminal Justice System as an Effort to... 
Juvenile delinquency is taken from the term Juvenile Delinquency, which was first displayed on the criminal justice agency in the United States in order to establish a child criminal justice law in the country. ${ }^{22}$ According to Romli Atmasasmita definition of Juvenile Delinquency is "Every act or behavior of a child under the age of 18 years is a violation of applicable legal norms and can endanger the personal development of the child concerned"23.

Meanwhile, Paul Moedikno gives the definition of Juvenile delinquency as follows: ${ }^{24}$

a. All acts which for adults constitute crime, for children constitute delinquency

b. All acts that violate the norms that interfere with public order committed by children

c. All actions that indicate social needs for children

Delinquency of children, which is a violation of applicable legal norms, is referred to as $\mathrm{ABH}$. Referring to the SPPA Law, ABH is divided into 3 (three) groups, namely children who are in conflict with the law, children who are victims of criminal acts, and children who are witnesses of criminal acts.

According to Apong Herlina, children who are in conflict with the law can also be said as children who are forced to conflict with the criminal court system because ${ }^{25}$ :

a. Suspected, indicted or found guilty of breaking the law;

b. Has become a victim due to a violation of law by a person/group of people/institution/ state against him;

c. Have seen, heard, felt or knew an event of violation of the law.

From the explanation above, can be concluded that, first, the conceptual of children in conflict with the law are children who are not yet 18 years old, and have never been married, who are suspected of committing a crime. Second, children who are victims of crime are children who are not yet 18 years old and have never been married who suffer physical, psychological and economic sufferings caused by criminal acts. Third, children who witness criminal acts are children who are not yet 18 years old and have never been married who provide information on the process of investigation, prosecution and trial ${ }^{26}$. In addition, children who are in conflict with the law can also be interpreted as children who have problems or children involved because of an act that is contrary to the law.

\section{Eliminatting Diversion Efforts}

\section{Elements of Guilts in Article 96 of the SPPA Law}

The SPPA Law regulates the process of resolving $\mathrm{ABH}$ cases from the investigation stage to the guidance stage after undergoing a crime through a diversion process aimed at achieving peace between victims and children, resolving cases of children outside the judicial process, avoiding children from deprivation of liberty, encouraging communities to participate, and instill a sense of responsibility to the child ${ }^{27}$.

At the level of investigation, prosecution, and examination of cases of children in the district court must be tried diversion. Child cases that are mandatory for diversion are criminal offenses that are punishable by imprisonment for less than 7 (seven) years and do not constitute repeat offenses ${ }^{28}$. Therefore, in the case of a public prosecutor who deliberately does not make an attempt to diversion, criminal sanctions are given.

22 Ibid, p. 29.

23 Wagiati Soetodjo. (2013). HukumPidana Anak (edisi revisi). Bandung: RefikaAditama, p.11.

24 Ibid, p. 9.

25 Apong Herlina, et.all. (2014). Perlindungan Terhadap Anak Yang Berhadapan Dengan Hukum. Jakarta: Buku Saku Untuk Polisi, Unicef, p. 17.

26 Angger Fuady. (2015). Sistem Peradilan Pidana Anak. Yogyakarta: med press, p. 17

27 Article 6 UU SPPA.

28 Article 7 UU SPPA. 
The existence of criminal sanctions in the SPPA Law aims to provide legal certainty for ABH to be sought diversion by law enforcers, because without a criminal provision the prohibition or obligation would not have any legal consequences at all, only meant as an appeal ${ }^{29}$.

According to Remmelink, basically the criminal provisions are ultimumremedium, but in the case of administrative sanctions are often not adhered to properly, it is necessary to impose criminal sanctions aimed at preventing law enforcement officers from avoiding the implementation of the obligations that have been determined.

If the public prosecutor has sought diversion, but the parties failed to reach an agreement in settlement of the case, then the public prosecutor is deemed to have carried out his obligations and cannot be convicted as referred to in Article 96 of the SPPA Law which reads:

"Investigators, public prosecutors and judges who deliberately did not carry out the obligations referred to in article 7 paragraph (1) shall be sentenced to a maximum imprisonment of 2 (two) years or a maximum fine of Rp 200,000,000 (two hundred million rupiah)."

In order for the Public Prosecutor to be subject to criminal sanctions as provided for in article 96 above, it must be proven in advance the element of error relating to criminal liability consisting of deliberate (dolus or opzet) and negligence (culpa $)^{30}$. So that when analyzed the elements of error contained in article 96 of the SPPA Law are as follows:

1. Investigators, Public Prosecutors and Judges ${ }^{31}$

The definition of a Public Prosecutor in Article 1, paragraph 6 letter b of the Criminal

Procedure Code is a prosecutor who has the authority to conduct prosecutions and carry out the determination of judges ${ }^{32}$. Moreover, the Public Prosecutor was also given another authority by the Law to diversify cases involving $\mathrm{ABH}$ as regulated in article 7, paragraph 1, and article 42, paragraph 1 of the SPPA Law.

2. Deliberately Not Performing Obligations

Deliberate or deliberate is a subjective element to determine whether or not someone can be held liable for a crime committed. Another term for deliberate words is opzet or dolus $^{33}$.

In criminal law, there are two types of intentional theory, namely the theory of the will (whilstheorie), and the theory of knowledge or the theory of imagining (voorstellingstheorie). Out of the two theories, Moeljatno is more inclined to the theory of knowledge or imagination. The reason is because knowledge is naturally engulfed in the will. Due to the desire of something, people must already have the knowledge (picture) about it.

Based on this theory, the public prosecutors who may be subject to article 96 are public prosecutors who intentionally based on knowledge do not carry out diversion obligations as regulated in article 7 paragraph 1 of the SPPA Law. However, with the Constitutional Court Decree Number 110 / PUU-X / 2012, Article 96 has declared invalid.

\section{The element of guilt in Article 95 of the SPPA Law}

Even though the Constitutional Court has declared article 96 unconstitutional or revoked by the Decision of the Constitutional Court Number 110 / PUU-X / 2012, that does not mean allowing law enforcers both police, judges and prosecutors not to carry out diversification obligations. Although criminal sanctions have been declared unconstitutional, the provisions of article 95 ruled administrative sanctions for officials or officers ${ }^{34}$ who violate the provisions,

29 Constitutional Court Decision Number 34/PUU-VIII/2010 p. 118.

30 Adami Chazawi. (2002). Pelajaran Hukum Pidana Bagian I, Jakarta: Raja GrafindoPersada, p. 90.

31 In this element, writer focuses merely on the public prosecutor.

32 M.Karjadi dan R.Soesilo. (1988). Kitab Undang-Undang Hukum Acara Pidana Dengan Penjelasan Resmi Dan Komentar, Politeia, Bogor, p 3.

33 Roni Wiyant. (2012). Asas-Asas Hukum Pidana Indonesia. Bandung: Mandar Maju, p. 201.

34 One of whom is the prosecutor.

70 Dewi Setyowati | Diversion in the Child Criminal Justice System as an Effort to... 
one of which is a provision for carrying out diversion as regulated in article 95 of the SPPA Law which reads:

Officials or officers who violate the provisions referred to in Article 7 paragraph (1), Article 14 paragraph (2), Article 17, Article 18, Article 21 paragraph (3), Article 27 paragraph (1) and paragraph (3), Article 29 paragraph (1), Article 39, Article 42 paragraph (1) and paragraph (4), Article 55 paragraph (1), and Article 62 are subject to administrative sanctions in accordance with the provisions of the legislation.

To find out the element of error contained in article 95 of the SPPA Law, specifically the mistakes of the Public Prosecutor in not carrying out the diversion are as follows:

1. Official or officer

Definitions of Officials, according to the Indonesian Dictionary (KBBI) are government employees who hold important positions, while officers are people who are tasked with doing something. Regarding the elements of officials and officers referred to in article 95 of the SPPA Law, it has an extensive scope. One of them is the Public Prosecutor.

The definition of a Public Prosecutor in Article 1 paragraph 6 letter $b$ of the Criminal Procedure Code is a prosecutor who has the authority to conduct prosecutions and carry out the determination of judges ${ }^{35}$. Moreover, the Public Prosecutor was also given another authority by the Law to diversify cases involving $\mathrm{ABH}$ as regulated in article 7, paragraphs 1 and article 42, paragraph 1 of the SPPA Law.

2. Violating the provisions referred to in Article 7 paragraph (1) of the SPPA Law

Lamintang stated that people generally only learned that the act was an unlawful violation so that it could be punished after the action was declared prohibited by law ${ }^{36}$. In the provision of Article 95 of the SPPA Law there are many restrictions, one of which is a prohibition for public prosecutors if they do not conduct diversion in the ABH case that has criteria for diversion, as the diversion order is regulated in article 7, paragraph 1 of the SPPA Law.

The ABH case requirements that must be implemented are based on the SPPA Act, which is as follows:

a. The age of the offender must be as a child, this is regulated in Article 1 paragraph 3.

b. There is a confession or statement of guilt from the perpetrator and his willingness to be diversified to instill a sense of responsibility to the child as stipulated in article 6 letter $b$.

c. There is agreement from the victim to carry out settlement outside the criminal justice system.

d. There is community support for carrying out settlement outside the juvenile justice system, Article 9 paragraph 1 letter $d$. The solution to the problem of criminal acts committed by children should not only focus on the relationship between the perpetrator and the victim, but also the relationship with the community must be considered.

e. Article 7 paragraph 2 of the SPPA Law regulates the conditions requiring child problems to be diversified, namely: Threatened with a maximum imprisonment of 7 (seven) years; Not a residivist.

With the existence of the obligation of the public prosecutor to diversify the $\mathrm{ABH}$ case that meets the above criteria, then if the public prosecutor does not carry out the diversion, it can be said to violate the provisions stipulated in article 95 of the SPPA Law.

3. Subjected Administrative Sanctions

Diversion is part of the event process, which is the administrative task of a prosecutor as a general supporter in carrying out his primary duties and functions. So if the public

35 M.Karjadi dan R.Soesilo. (1988). Kitab Undang-Undang Hukum Acara Pidana Dengan Penjelasan Resmi Dan Komentar. Bogor: Politeia, p 3.

36 Lamintang, Op.Cit, p. 210 
prosecutor does not carry out the diversion, it is more appropriate to be given administrative action following the Code of Attorney Conduct Number: PER-014 / A / JA/ 11/2012 because it is included in the scope of violations.

Violations are any actions of prosecutors who violate the obligations and/or prohibitions in the provisions of the Prosecutor's Code of Conduct, both those that are done on and off working hours. Administrative action is an action handed down to the Prosecutor who violates the Prosecutor's Code of Conduct, administrative actions consist of:

1) Exemption from the duties of a Prosecutor, a minimum of 3 (three) months and a maximum of (1) one year; and/or assignment transfer to another work unit, for a minimum of 1 (one) year and a maximum of 2 (two) years.

2) If during an administrative action, a Certificate of Personnel (Clearance of Personnel) is issued, then the administrative action is included.

3) After completing administrative actions, the Prosecutor concerned can be reassigned to the original place or other work units at the level of the work unit before transferred.

\section{Implications of MK Decision Number 110 / PUU-X / 2012 Article 96}

The existence of criminal sanctions in the SPPA Law aims to provide legal certainty for ABH to be sought diversion by law enforcers because without a criminal provision, the prohibition or obligation would not have any legal consequences at all, only meant as an appeal ${ }^{37}$. However, with the Constitutional Court Decree Number 110 / PUU-X / 2012 sanctions in the form of criminal threats if the law enforcers do not diversify the case that must be diversified as regulated in Article 96 of the SPPA Law becomes unconstitutional.

\section{CONCLUSSION}

At the substance of this material test, it mainly involves administrative tasks, which naturally become the duty of the prosecutor as the general public in carrying out their duties. Also, criminal sanctions against prosecutors who carry out abuse of administrative law (maladministrasi) should not be criminal, but in the form of administrative sanctions, resulting in criminalization. The 1945 Constitution of the Republic of Indonesia implicitly regulates the existence of the Republic of Indonesia Attorney's Office in the constitutional system. Republic of Indonesia Attorney's Office as a body associated with judicial authority, with a very dominant function as the principle of dominus litis, controlling the case process that determines whether a person can be declared a defendant and brought to court based on tools legal evidence according to the Law, and as executive ambtenaar executor of the determination and decision of the court in a criminal case. Judicial review against the SPPA Law is a struggle in the context of maintaining the constitutional rights of law enforcers in their duty and is not intended to reject diversion in handling $\mathrm{ABH}$. This constitutional right related to the protection of the law enforcement profession guaranteed by the constitution. However, even though the Constitutional Court has decreed that article 97 is unconstitutional or has abrogated, that does not allow law enforcers, namely the police, judges, and prosecutors, not to carry out diversification obligations.

\section{Bibliography}

Books:

Bimo Wologito. (2004). Kenakalan Remaja. Yogyakarta: Fakultas Psikologi UGM.

Arief Gosita. (1993). Masalah Korban Kejahatan. Jakarta: Akademi Pressindo.

37 Constitutional Court Decree Number 34/PUU-VIII/2010 p. 118.

72 Dewi Setyowati | Diversion in the Child Criminal Justice System as an Effort to... 
Maulana Hasan Wadong. (2000). Pengantar Advokasi dan Hukum Perlindungan Anak. Jakarta: Grasindo.

Irma Setyowati Soemitro. (2000). Aspek Hukum Perlindungan Anak. Jakarta: Bumi Aksara.

Wagiati Soetodjo. (2009). HukumPidana Anak. Bandung: Refika Aditama.

Legislation:

Undang-Undang Dasar Negara Republik Indonesia Tahun 1945.

Undang-Undang Republik Indonesia Nomor 8 Tahun 1981 Tentang Kitab Undang-Undang Hukum Acara Pidana.

Undang-Undang Republik Indonesia Nomor 23 Tahun 2002 Tentang Perlindungan Anak.

Undang-Undang Republik Indonesia Nomor 16 Tahun 2004 Tentang Kejaksaan.

Undang-Undang Republik Indonesia Nomor 11 Tahun 2012 Tentang Sistem Peradilan Pidana Anak.

Peraturan Pemerintah Nomor 65 Tahun 2015 Tentang Pedoman Pelaksanaan Diversi dan Penanganan Anak yang Belum Berumur 12 Tahun.

Peraturan Presiden Republik Indonesia Nomor 18 Tahun 2011 Tentang Komisi Kejaksaan Republik Indonesia.

Peraturan Jaksa Agung No. 006/A/J.A/2015 Tentang Pedoman Pelaksanaan Diversi pada Tingkat Penuntutan.

Putusan Mahkamah Konstitusi Nomor 110/PUU-X/2012.

Putusan Mahkamah Konstitusi Nomor 68/PUU-XV/2017. 